\title{
Beckwith-Wiedemann syndrome
}

INSERM

\section{Source}

INSERM. (1999). Orphanet: an online rare disease and orphan drug data base. BeckwithWiedemann syndrome. ORPHA:116

Beckwith-Wiedemann syndrome (BWS) is a genetic disorder characterized by overg rowth, tumor predisposition and congenital malformations. 